\title{
Towards Freedom: Documents on the movement for Independence in India 1938 - A case study of affairs in Sikar
}

\author{
Vijjika Singh \\ Assistant Professor, Daulat Ram College, University of Delhi, India
}

The Towards Freedom volumes have been edited by scholars of great distinction and eminence. ${ }^{1}$ They bring together historical materials relating to the period of 1937-47 from a wide variety of sources - official records, private and organisational papers, newspapers and other contemporary publications available within the country. As such they prove to be an important source of information to study the history of this period and provide clear and unbiased information regarding the ongoing mass movements as part of the freedom movements in various parts of British India and the Princely states, in the backdrop of the Gandhian movement. They clearly define the role of the Kisan Sabhas and Praja Mandals and how they influenced in shaping the ideology of mass movements not only in British India, but also in the Princely states. The Towards Freedom series was an answer which the Indian government decided to take out as a response to the 'Transfer of Power' documents from the British side.

Around the 1930s there was an increasingly democratic participation of Indians in the political process. Diarchy and dominion status was accorded and the Act of 1935 was in place. There were Congress Ministries in various provincial states. The people under Princely States did not have rights equal to the rights enjoyed by those of the British provinces. The rulers of the Princely states had imposed a number of restrictions on the rights of their subjects. This paper intends to focus on the affairs in Sikar, which was part of the princely state of Jaipur. Through official correspondence between Rao Raja, (thikanedar of Sikar) British officials stationed at Jaipur and Sikar and His Highness Maharaja of Jaipur, a petty issue of Hardayal Singh being taken to England turned out to be a more complex issue of Raja Rao of Sikar trying to assert his autonomy from the Jaipur State, which had the indirect control of British Raj on it as a result of British Paramountacy. ${ }^{2}$ The British Government studiously avoided precision in defining paramountacy in their exercise of power over Princely States. I would like to add here that the doctrines of British Paramountacy consisted of typical features such as titular ruler on the throne with access to income, supervisory role of British Political Agent and Committees and fixed tribute to be paid to Colonial Government etc. This fixed revenue led to higher land revenue demand from peasant communities in princely states and in return the princely States were given the right to continue with Begaar (forced labour) and to maintain greater control over police, partly as a way of controlling increasing radicalism of peasants and nationalists. These features were very much evident in the Princely state of Jaipur, and Sikar being one of the Thikanas (jagir), had since 1920s tried to establish its autonomy under Rao Raja on some pretext or the other. His Highness, following the same doctrine of British Paramountacy, was trying to control the affairs in Sikar, and thereby had decided to take Hardayal to England to control his behaviour and ideology . The official correspondence shows that the affairs in Sikar point out entire discussions on whether the British should act neutral or should be directly involved in the affairs of Sikar. Since Congress Ministries were in power after the elections of 1937, the British did not want to do anything that might have initiated agitation of any kind from the Congress or other associations.

Through my paper I would like to analyse the role of congress in the broader framework of the ongoing struggle of the people's movement in the Princely states, while viewing the peculiar case of Sikar . $\mathrm{By}^{3}$ far the most significant advance made by the nationalist movement during 1938 was in the Princely States. The year witnessed a remarkable upsurge in the movements for civil liberties and responsible governments in these states, and a switch in Congress's traditional policy of non interference in the affairs of the state to the one of active involvement in these movements.

Prior to 1920, the political and economic demands of the congress party totally abandoned the native states. Furthermore the Indian National Congress declined to engage in the democratic struggle of these Princely

\footnotetext{
1 Towards Freedom documents on the Movement for Independence in India 1938.- Editors note.

${ }^{2}$ Rajputana under British Paramountacy - The Failure of Indirect Rule- Susanne Hoeler Rudolph and Lloyd I Rudolph.

${ }^{3}$ Towards Freedom documents on the Movement fro Independence in India 1938.- Editors note. 
States. The policy decision was centred on the need to focus on the primary goal of attaining freedom from the British and to evade regional disintegration, as there were limited resources. The Congress party believed that it would dilute its agenda by working for increased political mobilization in Princely States. After the States People's Conference in Bombay in 1927, the INC allowed people from different Princely States to join the party and the Indian freedom Struggle. The civil disobedience movement produced a deep impact on the minds of the people of these states and stirred them into political activity. In 1938 when the Congress defined its goal of independence, it also included the independence of the Princely States, as if to emphasize the common national aims of the political struggles in British India and in the States. Pt Motilal Nehru underlined the' historical ,religious, sociological and economical affinities between the people of British India and those of the Princely states. By 1938 Congress sanctioned the organisation of Congress Committees in Princely states, provided they undertook neither parliamentary activity nor direct action in Congress's name .

In the affairs of Sikar, this involvement is clearly visible due to mediation of Jamnalal Bajaj and G D Birla, prominent marwaris who belonged to this region. Through their newspaper they tried to create political awareness at a national level and brought to the fore democratic struggles in the Princely States. Sikar, otherwise a small nosdescript place, acquired national importance. The close association of Bajaj and Birla with Congress and Gandhi unfolded an interesting turn of events at Sikar where they used their newspapers such as Hindustan times etc to propagate nationalist ideas based on Gandhian methods. They also sent delegates to the Viceroy to settle the affairs at Sikar.They created an atmosphere of mass mobilization to achieve democratic processes by creating political awareness amongst masses in Princely States which the Raj referred to as 'mob 'or 'crowd '.The British involvement was sought both from the side of the Durbar as well as that of Raja Rao. However the British Raj was somewhere apprehensive about the sudden outburst of this peoples' movement quite replicating the mass movements in the British ruled India . The Congress also maintained its policy of non violent methods in their demonstrations. Even at the height of the movement when all conciliatory talks failed and when there was fear of a violent outburst by the people who were supporting Raja Rao, pamphlets were distributed in Hindi to adopt non violent methods of protest and to keep the movement peaceful. The role of the vernacular press became very important here because all sorts of nationalist ideas were propagated through them, and the height of political awareness was witnessed not only in British India but also in the Princely States. The Gandhian methods were replicated to the extent that the Rani of Sikar went on a hunger strike to protest against her son Hardayal being taken to England without getting married.

The role of congress nowhere was directly seen in the Sikar affairs. However undercurrents of Congress involvement were felt through the role of Praja Mandals, the Kisan Sabhas and the socialist and Nehruvian ideologies in the form of the protest of Jat peasants against the Rajputs .By $1939^{5}$, Gandhi personally backed the States Peoples Freedom Movement, as it became known, to the extent of reviewing and guiding all the activities of the Jaipur Praja Mandal - the popular movements organisation in that state. He was drawn into its activities by his close friend and disciple Bajaj, a wealthy Rajasthan businessman, long time Congressman, and treasurer of the Indian National Congress. Bajaj, as president of Jaipur Praja Mandal, was refused entry to the state, and the Mandal was was forbidden to hold public meetings and proceedings .Bajaj and his followers offered passive resistance and were sent to jail. In fact ${ }^{6}$ the neutrality of the Congress Party towards the Popular movements in Princely States was merely a tactical device that should not be confused with its strategy. It would be true to assert that the peasant movements in the state were not directly organized by the congress, and that the local organizations actively involved in the movements were formally 'independent ' of the congress. The Jat peasants were rich peasants who were trying to establish their identity since early 1930s, their main targets being the Thikanedars, mostly Rajputs and the Kayamkhanis. ${ }^{7}$ They were also demanding a responsible government in the princely states quite similar to the peasant movements in British India and a restructuring of power relations on a democratic basis, in which they and other subaltern group could participate in the political processes, irrespective of their class and caste. The British on the other hand were trying to use groups whether they were Jat or Muslim or Rajputs; against each other, by treating them as different identities.

\footnotetext{
${ }^{4}$ Princely States, Peasants Protest and Nation Building in India : The colonial mode historiography and subaltern studies - Hira Singh

${ }^{5}$ Rao Rajput. Parivar. Page4. Me/rajputana kinddoms.html.

${ }^{6}$ Princely States, Peasants Protest and Nation Building in India : The colonial mode historiography and subaltern studies - Hira Singh

${ }^{7}$ Princely States, Peasants Protest and Nation Building in India : The colonial mode historiography and subaltern studies - Hira Singh
} 
In the Sikar affairs it becomes evident that the Jats and the Muslims were not on the side of Raja Rao, for the Rajputs and Bhumias were seen as exploiters by these groups. The peasant agitation by the Jats was pitted primarily against the Jagirdars and not against the Durbar or the British Raj.

The role of the Praja Mandals also became important ${ }^{8}$ The most important contribution of these organisation was to break the insularity of the peasant movements by linking them with one another in different princely states, as well as with peasant movements in British India. This was a significant step in creating a sense of unity of peasants as a class cutting across the division between the two Indias. The petty issue of Hardayal being sent to England by His Highness of Jaipur turned into a movement inspired by the nationalist movement and Raja Rao treated it as a pretext to declare his autonomy, against the Durbar . The Jaipur Praja Mandal, which was revived in 1936, aimed at the attainment by lawful and constitutional means and establishment of responsible government under the aegis of his highness, the Maharaja Bahadur. The Praja Mandal sought to work in close cooperation with state officials . ${ }^{9}$ In the ' Sikar rebellion', the backward looking Rao raja of the largest estate in Jaipur asserted the claims of feudal liberty against those of centralising absolutism, in resisting the Maharajas British- Officered armed forces . In this struggle between the prince and the feudal aristocrat, the middle-class Jaipur Praja Mandal to a degree backed the claims of Sikar in an effort to advance the fortunes of representative government and public liberties. At the same time, the Maharaja was inclined to be more sympathetic to the Praja Mandal under the Jaipuri leadership of Bajaj, than was his government under the direction of a British Prime Minister.

Another remarkable feature of the Sikar affairs was the role of media where information was constantly being relayed between the officials of Jaipur Durbar and those of the British Raj. The frequent exchange of telegrams and letters and role of newspapers cannot be negated. Up until 1930s the Princely States had managed to keep the presence of newspapers and periodicals at a minimal level. Some princely States required even typewriters to be registered. Places like Ajmer which were islands of British India surrounded by Princely States were used for printing newspapers and pamphlets which were then smuggled into Princely States of Jaipur. The first wave of newspapers and periodicals came about mostly, though not exclusively, by Brahmin and Kayastha school masters such as Hiralal Shastri and Haribabu. They were also supported by some members of the merchant caste, such as Jamnalal Bajaj and G D Birla. Summarily the role of media by 1938 became quite important in the Princely state of Jaipur and was able to create public opinion amongst the masses or people of the princely states, who by now were getting mobilised towards democratic processes in the princely states in India, just as they were in other parts of British India.

To sum up 'Towards Freedom Volumes' provide a powerful insight in assessing ${ }^{10}$ the attitude of the people of Princely states towards their rulers, the increasing link between the colonial state and the paramountacy and above all the relations between the people of the Princely States and those of British India . The volumes through official records and letters provide an unbiased and unmitigated opinion of the mass movements in the Princely States in the backdrop of a powerful national movement inspired by Gandhian ideology. The petty issue of Hardayal was taken as a pretext to voice the opinion of the people living in the princely State of Jaipur, and a series of incidents then unfolded the response of various classes and castes towards British Paramountacy.

[1]. British Policy towards Princely States of India - Vyas , R P

\section{Bibliography}

[2]. Annals and Antiquities of Rajasthan - Tod James

[3]. Peoples Movement in the Princely States - Vaikuntham, Y

[4]. Editorial Note on Towards Freedom Series

[5]. RajputanaUnder British Paramontacy - The Failure of Indirect Rule- Susanne Hoeler Rudolph and Lloyd I Rudolph

[6]. Indias princely States: People Princes and Colonialism edited by Waltraud Ernst and Biswamoypati

[7]. Princely States, Peasants Protest and Nation Building in India : The colonial mode historiography and subaltern studies - Hira Singh

[8]. The princes of india in the endgame of Empire, 1917-1947- Ian Copland

[9]. Review of The Indian princes and their States by Barbara N Ramusack - G S Sahota

\footnotetext{
${ }^{8}$ Princely States, Peasants Protest and Nation Building in India : The colonial mode historiography and subaltern studies - Hira Singh

9 Rao Rajput. Parivar. Page4. Me/rajputana kinddoms.html.

10 Peoples Movement in the Princely States - Vaikuntham
} 